\title{
Insurrection for land, sea and dignity: resistance and autonomy against wind energy in Álvaro Obregón, Mexico
}

\author{
Alexander Dunlap ${ }^{1}$ \\ Vrije Universiteit Amsterdam, The Netherlands
}

\begin{abstract}
Providing a glimpse into the reality of wind energy development, the story of Álvaro Obregón is one of resistance. Álvaro Obregón is a primarily Zapotec semi-subsistence community located near the entrance of the Santa Teresa sand bar (Barra), where in 2011 Mareña Renovables initiated the process of building 102 wind turbines. Demonstrating the complicated micro-politics of land acquisition, conflict and unrest, this article argues that climate change mitigation initiatives are sparking land grabs and conflict with the renewed valuation of wind resources. Insurrection against the Mareña Renovables wind project has spawned a long-term conflict, which has created social divisions and a type of low-intensity civil war within the town. This article will chronicle the uprising against the wind company, battles with police, and the town hall takeover, which includes analyzing the conflict taking place between the cabildo comunitario and the constitucionalistas. Subsequent sections examine the different perspectives within the village and how this battle between the Communitarians and the wind company continues today. The article reveals the complications associated with land deals, the conflict generating potential of climate change mitigation practices and, finally, concludes by reflecting on the difficulties of formulating alternatives to development within a conflict situation.
\end{abstract}

Keywords: Oaxaca; Álvaro Obregón, sustainable development, wind energy, green grabbing, resistance, climate change

\section{Résumé}

L"histoire d"Álvaro Obregón, dans le panorama des différents projets de développement de l"énergie éolienne, est une histoire de résistance. Álvaro Obregón est une communauté semi-autonome zapotèque près de l"entrée du bar de sable de Santa Teresa à Oaxaca, au Mexique. Là, en 2011, Mareña Renovables a commencé le processus de construction de 102 éoliennes. Élaborant les micropolitiques compliquées de l"acquisition des terres, des conflits et de l"agitation, l"article soutient que les initiatives visant à atténuer les effets du changement climatique conduisent souvent à l"expropriation des terres et aux conflits sociaux. La résistance au projet Mareña Renovables a conduit à un conflit prolongé, créant des divisions sociales et une sorte de guerre civile de faible intensité. $L$ "article reconstruit chronologiquement la résistance contre l"entreprise, les batailles avec la police et l"occupation de la municipalité, et comprend une analyse du conflit entre deux partis locaux, le conseil de la communauté et les constitutionnalistes. Les sections suivantes examinent ces différentes perspectives au sein de la communauté et reconstruisent la façon dont la bataille entre la communauté et l"entreprise s"est poursuivie. L"article révèle ainsi toutes les complications qui se présentent dans des cas comme les conflits fonciers, la possibilité de générer des conflits forts à cause des pratiques visant à atténuer les changements climatiques et la réflexion sur les difficultés de formulation d"alternatives de développement. dans des situations de conflit.

Mots-clés: Oaxaca; Álvaro Obregón, développement durable, énergie éolienne, poignée verte, résistance, changement climatique

\footnotetext{
${ }^{1}$ Dr. Alexander Dunlap is a post-doctoral researcher in the Department of Social and Cultural Anthropology at Vrije Universiteit Amsterdam, the Netherlands. Email: alexander.a.dunlap "at" gmail.com. His work has critically examined police-military transformations, market-based conservation, wind energy development and extractive projects more generally in both Latin America and Europe. He has published in Anarchist Studies, Geopolitics, Journal of Peasant Studies, Human Geography, Capitalism, Nature, Socialism, Political Geography and a recent article in The International Journal of Human Rights. This article would not have been possible without a great variety of support from people in and outside Mexico. In Oaxaca, Alma, Jack C., Anna, Mr. X, Flaco, La Banda, the Cabildo Comunitario, and many more. Outside Mexico includes Paul R., Ton Salman, Judith Verweijen, Andrea Brock, Dimitris Dalakoglou, the editors of JPE and the anonymous reviewers, all of which have dedicated time, patience and feedback to this research article.
} 


\section{Resumen}

La historia de Álvaro Obregón, dentro del panorama de diferentes proyectos de desarrollo de energía eólica, es una historia de resistencia. Álvaro Obregón es una comunidad zapoteca, semi autosustentable, ubicada cerca a la entrada de la barra de arena Santa Teresa, en Oaxaca, México. Allí, en 2011, la empresa Mareña Renovables inició el proceso de construcción de 102 turbinas eólicas. Exponiendo las complicadas micro-políticas de adquisición de tierras, del conflicto y la agitación, el artículo sostiene que iniciativas para mitigar efectos del cambio climático, muchas veces llevan a la expropiación de tierras y conflictos sociales. Resistencia contra el proyecto de Mareña Renovables llevó a un prolongado conflicto, creando en esta población, divisiones sociales y una suerte de guerra civil de baja intensidad. El artículo reconstruye cronológicamente la resistencia contra la empresa, las batallas con la policía, y la ocupación de la municipalidad, e incluye un análisis del conflicto entre dos partidos locales, el cabildo comunitario y los constitucionalistas. Las siguientes secciones examinan estas diferentes perspectivas dentro de la comunidad, y cómo la batalla entre los comunitarios y la empresa ha persistido hasta hoy. El artículo así revela todas la complicaciones que surgen en casos como éste, cubriendo temas como conflictos sobre tierra, el potencial de generar fuertes conflictos a causa de prácticas dirigidas a atenuar cambios climáticos, y concluye con una reflección sobre las dificultades de formular alternativas de desarrollo dentro de situaciones de conflicto.

Palabras clave: Oaxaca, Álvaro Obregón, desarrollo sostenible, energía eólica, agarre verde, resistencia, cambio climático

\section{Introduction}

Invited into a backyard shaded by Tamarind trees, the human right defenders pull up chairs. I sit down and one defender picks up a stick and begins drawing a map of the coastal Isthmus of Tehuantepec (Figure 1), known locally as the Istmo, in the loose dirt on the ground. They begin by telling the history of wind parks in the region and the resistance that emerged against them. Pointing to the Barra de Santa Teresa (Barra), the defender explains how "there is a 1,000 year old cultural identity and it has a lot to do with the sea, with the wind - this is a sacred place" for the people living around the Lagoon and who "come to the Barra to do their rituals." Explaining the conflictive fault lines in the region, one human right defender continues:

Even though the Zapotecs are in the north, the Ikoots are in the south, it never crossed the mind of the government that people from Álvaro Obregón would unite with people from San Dioniso del Mar and San Mateo del Mar to oppose Mareña Renovables. Why? Because historically these people have been passive, they are a peaceful people, but the government hit them where it hurts-in the Barra. The [Mexican] government did not expect this conglomeration of forces. Because the opposition was traditionally in the northern part of the Istmo, where people are politically aware, historically violent people ready to defended their rights and yet they sold their land [to the wind companies]. There was a different way of thinking here [in the south]. First, the company went into San Mateo del Mar, they entered over here [pointing to the map]. They went to the assembly, proposing to enter from here to build in Santa Maria and on the Barra. San Mateo was the first town that said: 'No!' The assembly said: 'You will not enter. ' So that entrance was cut off on that side. So there second option was 'let's enter through Álvaro Obregón.'

Since 2011 conflict has raged between the "Triangle of Resistance"— San Dionisio del Mar, San Mateo del Mar and Álvaro Obregón —against the Mareña Renovables wind project, or Mareña for short, that sought to build 102 wind turbines on the Barra and another 30 on the Pacific Ocean around Santa Maria del Mar. While the Barra is part of San Dionisio County, Álvaro Obregón is located near the only land entrance to the Barra, making it an important point of vehicular access, but also a strategic bottleneck to halt construction.

\footnotetext{
${ }^{2}$ Interview 6.3, March 21, 2015.
} 


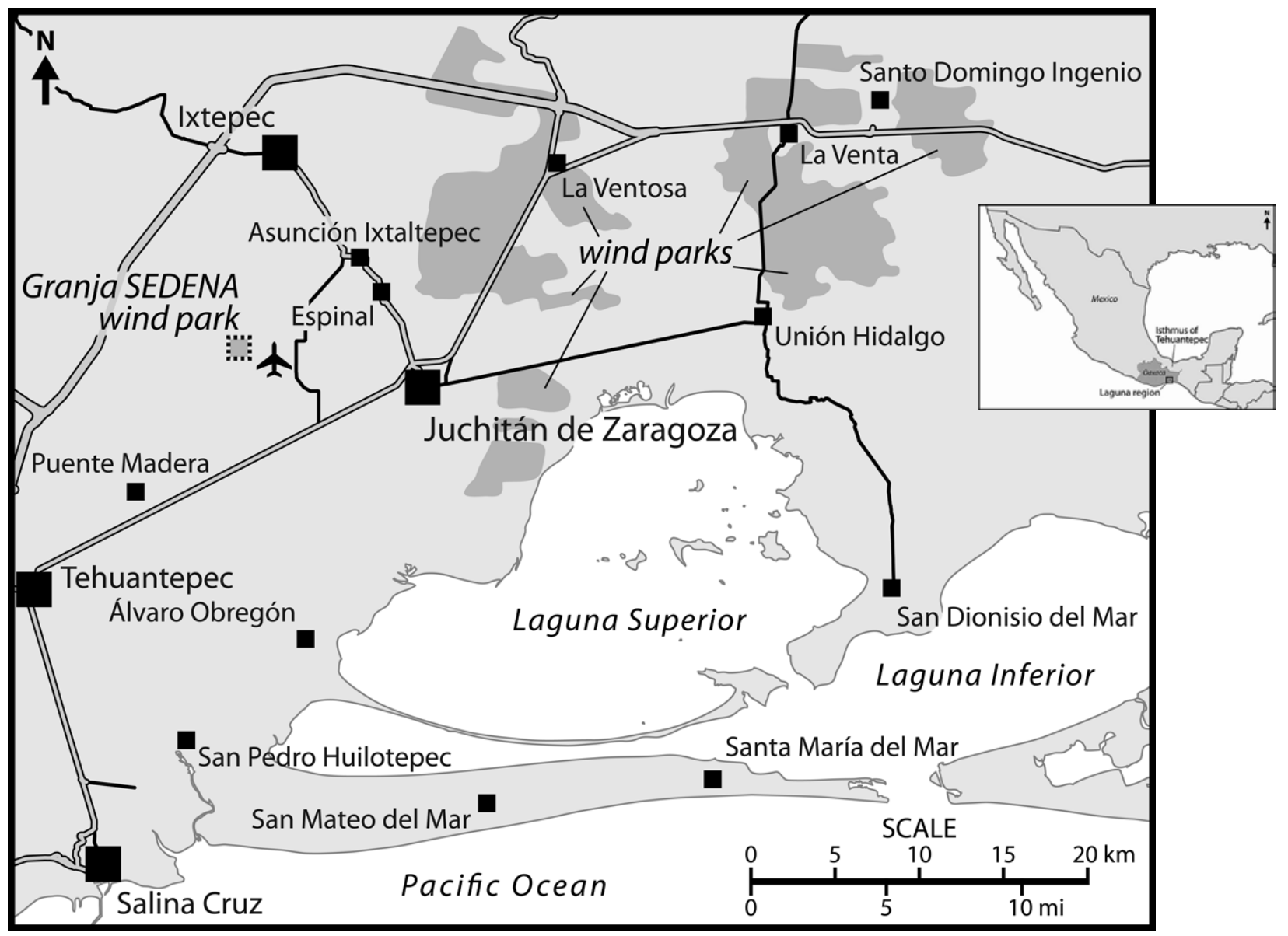

Figure 1: The coastal Istmo. Maps by Carl Sack.

Wind energy development is primarily concentrated in the northern coastal Istmo. Neoliberal economic policy in Mexico, the Plan Puebla Panama/Mesoamerica (2001) industrial corridor, and green economic and climate change legislation have all paved the way for a "wind rush" in the region (Altamirano-Jiménez 2017; Avila-Calero 2017; Dunlap 2017b). Embraced by various elites across the political spectrum, wind energy became a means to wealth creation, and social, sustainable and collective development (Dunlap 2017b; Howe and Boyer 2015; Hamister 2012; Nahmad et al. 2014; Simon 2013). Initially, the public had little idea what wind energy was, the projects' scale, or its social and ecological implications (Dunlap 2017b). The wind companies entered towns through local elites and land owners, who helped facilitate land deals and the arrival of wind projects (Dunlap 2017b; Friede 2016; Juárez-Hernández and León 2014; Nahmad et al. 2014). In 2005, however, contestations began to emerge. Residents denounced the lack of public consultation, environmental impact information and land contracts acquired through deception with unequal, even exploitative, terms of conditions - especially compared with countries in the Global North (Altamirano-Jiménez 2017; Friede 2016; Ocearnsky 2011; Wood et al. 2012). The acceptance and construction of wind turbines, despite popular discontent, left northern towns fighting for greater incorporation into individual and collective land deals, social development and free and/or reduced electricity prices (Dunlap 2017b; Friede 2016; Nahmad et al. 2014). Despite local contestations, transnational wind companies planned to cover the entire region with wind parks. Wind projects began spreading south to the Lagoon, the Pacific Ocean and on the Barra (Figure 1). Land contracting and related issues were similar in the South (as will be discussed below), except now wind parks were planned on the Barra and next to the Lagoon, triggering militant opposition and resistance. The North and South Coastal Istmo represent two different archetypal, yet overlapping, forms of resistance that are revealing 
of their respective situations (Borras et al. 2012). Opposition in the North is centered on unequal, exploitative land deals and labor contracts as locals fight for greater incorporation, while the South has increasingly positioned itself in total rejection of corporate wind parks (Altamirano-Jiménez 2017; Avila-Calero 2017; Dunlap 2015, 2017a; Howe 2014; Howe et al. 2015; Nahmad et al. 2014). By January 2015, the Istmo was covered with 1,608 wind turbines that occupied 17,867.80 hectares of land (Navarro and Bessi 2015; Rivas 2015). This has continued to be a source of conflict (Dunlap 2017d).

Located at the entrance of the Barra, Álvaro Obregón, or Gui'Xhi' Ro in Zapotec, embodies this insurrectionary tension against wind park development. This article offers an in-depth look to the "political reactions from below" (Hall et al. 2015), documenting the wind energy conflict through the experience of the resistance. It also analyses the subsequent low-intensity civil war dynamics within the town between the Community Council (cabildo comunitaria) and Constitutionalists. This research is foregrounded by insights from political ecology (Martínez-Alier 2002; Zografos and Martínez-Alier 2009) and critical agrarian studies (Borras et al. 2012; Hall et al. 2015), specifically the literature on "green grabbing" (Cavanagh and Benjaminsen 2017; Corson et al. 2013; Fairhead et al. 2012). Political ecology offers the concept of ecological distribution conflicts that Christos Zografos and Joan Martínez-Alier (2009: 1729) define as "struggles for redressing emerging or existing power inequalities and unequal distribution of costs and benefits resulting from landscape or ecological change" arising from developmental interventions. This has been demonstrated in the Northern Istmo (Avila-Calero 2017; Dunlap 2017b), while Avila-Calero (2017) further documents the uneven distributional impacts and "center-periphery" dynamic resulting from the Mareña Renovables project in San Dionisio del Mar. The micro-politics of governance reveals the relationships underlining land deals, their specific affinity to the state and their reliance on various forms of coercion, concession and/or deception to achieve the desired goals of land and resource control.

This article analyses the impact of the Mareña Renovables project on Álvaro Obregón. Revealing related conflict and resource distribution dynamics within Gui'Xhi' Ro, it is argued that climate change mitigation initiatives are reproducing top-down development approaches (characteristic of mineral and fossil fuel extraction) that revive and exacerbate conflict over new natural resource valuations, in this case the wind. Market-based approaches are incentivizing new valuations of ecosystems that legitimize the commodification and appropriation of natural resources (Corson et al. 2013). This appropriation is called green grabbing, which transfers the control of land and/or natural resources to powerful actors by various means using an environmental ethic or rationale (Fairhead et al. 2012). This market-based appropriation becomes intimately intertwined with anthropogenic climate change, not only as a "solution" or principal mitigation approach (Dunlap and Fairhead 2014), but also as the primary cause of ecological distribution conflicts that, without redress, turn into contested green grabs. Simon Dalby (2013: 35) highlights "industrial humanity" and the global economy as the essential driver behind climate change, while others acknowledge the conflict-generating potential of sustainable development interventions in the name of climate change mitigation strategies (Dabelko et al. 2013; Hunsberger et al. 2017; Taylor 2013). Dunlap and Fairhead (2014: 950) write "actions to mitigate climate change through market mechanisms act directly and indirectly to make politically feasible economic processes that contribute to, and spread low- and high-intensity conflict around 'natural resources'." The case of Álvaro Obregón exemplifies this concern, providing a detailed study documenting the reactions and social fractures of a primarily Zapotec Indigenous community with the arrival of a wind energy megaproject supported by climate change legislation.

This article is based on participant observation along with 34 different recorded semi-structured interviews conducted between 15 January and 20 May 2015 in Gui'Xhi' Ro. Entering the village though solidarity networks, the emphasis was on the lived experiences of people and conflict dynamics arising from wind energy development. These voices are often discredited by wind companies, the Mexican government and the mainstream media (see Bárcenas 2016). The number of men interviewed was almost double that of women, while the number of third gender-"muxes"—-was much less. Research participant confidentiality, especially given the conflictive nature of the town, is particularly important. Research participants are referred to by gender or by means of broad identity descriptors-for example "farmer," "fisherman" or fake names related to animals they had existing relationships or affinity. Fieldwork ended early due to repression, which was related to my participating with the groups in resistance in the region. This included embedding part-time with the polícia 
comunitaria, but also going fishing, attending public events and ceremonies with member of the resistance in Álvaro Obregón. Additionally, research was conducted with an interpreter with ties to the resistance.

The next section proceeds with a brief historical background of Álvaro Obregón/Gui'Xhi' Ro, which leads to documenting the arrival of the Mareña project from the perspective of residents in Gui'Xhi' Ro. The subsequent section discusses the various reasons that triggered an insurrectionary fury against the wind project and the Mexican political system itself. Subsequently, this includes outlining the different conflictual fault lines and political factions in Gui'Xhi' Ro. This situation demonstrates how climate change mitigation strategies work to further capture wind resources, triggering conflict and struggles for Indigenous autonomy when old political dynamics and new "climate friendly" development projects meet in Álvaro Obregón. The article concludes by discussing the difficulties facing the resistance and the possibilities they created for alternative development, which still await its realization.

\section{2. Álvaro Obregón: from agrarian struggle to wind park penetration}

Oaxaca State is the most culturally and biologically diverse state in Mexico and home to sixteen different Indigenous languages (Stephen 2013). Zapotecs remain the dominant ethnic group in the coastal Istmo region, after colonizing the region in the fourteenth century. In colonial times, the Istmo was in a strategic position for maritime commerce and experienced various phases of colonial integration/adaptation, famine and deaths before Mexico's 1821 Independence (Zeitlin 1989). Nation-state building and unification became a long and turbulent process in the Istmo (Smith 2009; Tutino 2007). Álvaro Obregón was established as an agricultural military colony by Heliodoro Charis Castro in 1930. Serving under the soon-to-be Mexican President Álvaro Obregón (1920-1924) during the Mexican Revolution, Charis named the town after him (Smith 2009). With 400 troops, Charis sought to impede control exerted by the Oaxacan governor over the Istmo by expropriating the estate of Baron Maqueo to create a home and a political power base in Gui'Xhi' Ro/Álvaro Obregón (Monjardin 1993; Smith 2009). The house, nearly a century later, became the headquarters of the wind energy resistance in 2012-2013 (Figure 2). After his triumphant return to the Istmo and with the support of President Lázaro Cárdenas, General Charis emerged as a political boss of the region (cacique) (Smith 2009).

Nominally associated with the Institutional Revolutionary Party (PRI), Charis acted as a highly respected Istmeño cacique for twenty-five years. Negotiating modernization and the Mexican state's involvement in the region, Charis fought for the social welfare of the region, promoting the development of schools, hospitals and running water and he was a strong defender of Zapotec culture (Rubin 1997). According to Jeffery Rubin (1997: 45), this permitted the region to become a "domain of sovereignty." While his position as cacique was not uncontested, Charis held the position until his death in 1964. Subsequently, a power vacuum emerged in the region, which led to social conflict and land grabs by political opponents and government functionaries. At the same time, political parties attempted to harness his popular mythology to gain political power in the region (Monjardin 1993). In 1964, the daughter and widow of Charis, also associating with the PRI, claimed his assets and sold some of his collectively-used land and salt flats in Álvaro Obregón to Federico Rasgado who, "employed armed guards to prevent peasants from fishing and gathering firewood and paid salt workers less than minimum wage, denying them social security and threatening them with violence" (Rubin 1997: 114). This resulted in repeated beatings and later killings in the town as people rejected this privatization of social property, which people felt tarnished the legacy of Charis.

Agrarian conflicts and the increasingly apparent tyranny of the PRI slowly gave way to the formation of the Isthmus Coalition of Workers, Peasants and Students (COCEI) ${ }^{3}$ in 1973 (Campbell et al. 1993). Throughout the 1970s and early 1980s, the COCEI achieved popular agrarian victories against the owners of private property. In particular, they managed to terminate the Communal Land Commission, establish ejidos and defended peasant land rights within the Istmo (Rubin 1997). Social property — ejidos and communal landappeared in Article 27 of the 1917 Mexican constitution. Ejidos are land designated for residential and agricultural use, governed by local assemblies made up of recognized community members ${ }^{4}$ and could not be

\footnotetext{
${ }^{3}$ Coalición Obrerea Campesina Estudiantil del Istmo.
}

${ }^{4}$ Traditionally all male. 
sold as private property until alterations to Article 27 in 1992 (Stephen 2002). The Mexican state, under Article 27, retains "direct ownership of all natural resources" below ejido topsoil (MG 2007: 19), which positions ejidos as strategic agrarian concessions by the Mexican state to pacify revolutionary tensions, promote state unification and reconstitute subsistence production (Tutino 2007: 242-5; Smith 2009). Communal land (comunales), in turn, relates to pre-colonial land claims and is governed by the community with varying rules and relationships according to regional customs and practices (Binford 1985; Dunlap 2017a).

The leaders of the COCEI, Héctor Sanchez, Leopold de Gyves and Daniel Nelio among others, soon joined the agrarian struggle in Álvaro Obregón (Rubin 1997). In 1977, the COCEI occupied the headquarters of the Ministry of Agrarian Reform in Mexico City. This action eventually led to a presidential decree awarding one thousand hectares that same year to the farmers of Álvaro Obregón, establishing what would become the pro-COCEI ejido_Ejido Emiliano Zapata in 1977 (Campbell 1994). The COCEI in Álvaro Obregón used the ejido to fight the PRI and strengthen their political power in the town. ${ }^{5}$ In 1981, Ejido Charis was formed by Charis's daughter and the PRI to counter the COCEI in Álvaro Obregón, but, as Campbell (1994: 276) describes, Ejido Charis eventually became "COCEI partisans." The roads to the Barra, the beaches and other lands were considered communal, until authorities from San Dionisio leased the Barra to Mareña Renovables.

This victory, combined with years of militant struggle against the PRI and Mexican state, eventually transformed Álvaro Obregón into a COCEI stronghold—not only with popular support, but also as a home to armed militants who defended the popular interest of the COCEI against other armed political formations in the region. While armed politics did not reach the same intensity as in Central America in the 1980s (Menjívar and Rodríguez 2005), the COCEI's success in the Istmo came at the cost of violent repression at the hands of the federal, state and extra-judicial forces associated with the PRI. ${ }^{6}$ Beatings and disappearances of COCEI supporters were frequent, with occasional killings. The determination of the COCEI led to electoral victory in Juchitán by 1981. Two years later, however, the military invaded the city, occupied it and evicted the COCEI from government (Campbell et al. 1993). In this context of deadly repression, the COCEI began cooperating with the PRI in 1986 and with President Carlos Salinas de Gortari in 1989. They eventually signed the Pacto de concertación social that granted Juchitán federal funds (Rubin 1997). This led to their integrated cooperation with the state and federal government, and later taking a soft stance against Plan Pueblo Panama and tolerating multinational corporations such as Walmart and transnational wind energy companies (Altamirano-Jiménez 2014). By the mid-2000s, a wind rush engulfed the Istmo and wind parks spread to the Lagoon and Barra de Santa Teresa.

\section{Mareña Renovables enters the Barra}

Embraced locally by politicians, the Mareña Renovables wind project is supported by a mix of 'green economy' and climate change mitigation polices (Avila-Calero 2017; Dunlap 2017b). Mexico received thirteen structural adjustment loans from the World Bank from 1980-1991 (Paley 2014), which continued and eventually intertwined with climate change legislation (Dunlap 2017b). Three notable policies laid the foundation for the Oaxacan wind rush. First was the revision of Article 27 in 1992 that created the possibility of privatizing social property—ejidos and communal land. The Second was the 1992 electricity law that contains a notion of "selfsupply" (autoabastecimiento) that allows companies to buy and manage their own energy generation sites. Third, NAFTA allowed self-supply to go transnational, stating in Section 6 that "an enterprise may acquire, establish, and/or operate an electrical generating facility in Mexico to meet the enterprise's own supply needs" (USAID 2009: 2). This incentivized transnational companies to invest in Mexico, simultaneously merging with the construction of a green economy and climate change mitigation policy.

The Law for the Development of Renewable Energy and Energy Transition Financing (LAFAERTE 2008) mandates that thirty-five per cent of electricity must come from renewable resources by 2020, forty percent by 2040 and fifty percent by 2050. Furthermore, according to The General Law on Climate Change

${ }^{5}$ Article 27 allows ejidatarios to have a rifle for hunting and a shotgun to defend the land, providing political parties armed supporters.

${ }^{6}$ Committee for the Defense of the Rights of People of Juchitán. 
(2012), this will be accomplished using "an incentive-based system, which promotes and allows for profitable electricity generation through renewable energy such as wind, sun, and small hydro" (LGCC 2012: 65; emphasis added). This "incentive-based system" is a reference to market-based environmentalism (Corson et al. 2013; Dunlap 2017b), which after the Kyoto Protocol (1997) became the principal approach to mitigate climate change and biodiversity loss (Dunlap and Fairhead 2014).

It is within this context that the Mareña Renovables wind project emerged, receiving loans from the United Nations Clean Development Mechanism (CDM) and Inter-American Development Bank (IBD) alongside investors from the Maquarie Group, Mitsubishi, FEMSA and the Dutch pension fund PGGM that sought to use the proposed energy to power Coca Cola, Heineken, Walmart and Grupo Bimbo among other shareholders (Avila-Calero 2017; Howe 2014; Smith 2012). Development of the Mareña began in 2004. The San Dionisio collective land commissioner (comisariado) Alvaro Sosa, without the knowledge of residents, accepted a bribe and signed a preliminary contract to lease the 1,643 hectares of the Barra to the Spanish corporation Preneal (Smith 2012). Once Preneal merged into the Spanish consortium Mareña Renovables, in 2007 they began conducting negotiations with politicians to build 102 wind turbines on the Barra and another 30 on the Pacific Ocean around Santa Maria del Mar. Eventually, the PRI-affiliated mayor of San Dionisio del Mar, Miguel López Castellanos, was paid between 14-20 million pesos in 2011 (US\$1-1.5 million) to allow construction on the Barra (Smith 2012). This included the construction of three electric substations; a submarine cable (less than $1 \mathrm{~km}$ long); fifty-two kilometers of high voltage transmission lines from the Santa Maria Substation to Ixtepec; and six docking stations to facilitate maritime access, as well as improving old roads and constructing new ones (IDB 2011). Mareña Renovables became the largest wind energy project in Latin America with 394 megawatts (MW) and the only wind park in the world proposed on a sand bar (Howe 2014). Appropriating the name "sea people"-Mareños - into the company name, ${ }^{7}$ after a court injunction (amparo) in 2012 and militant opposition from San Dionisio del Mar, San Mateo del Mar and Álvaro Obregón—"the triangle of resistance"— Mareña Renovables halted temporarily (Peterson 2012). Eventually, Mareña Renovables changed their name to Eólica del Sur and their project location in the Istmo, which was subjected to a free, prior and informed consent (FPIC) consultation (Dunlap 2017c). However, the conflict triggered by this wind project was far from over in Álvaro Obregón. In fact it had only begun.

\section{The seeds of conflict in Álvaro Obregón}

Mareña Renovables came to Álvaro Obregón to survey the area in 2011. While there are private homes and land in Álvaro Obregón, the area around the town consists of two ejidos: Zapata and Charis, and there are communal land and roads that lead to the Santa Teresa sand bar. Local COCEI political leaders ${ }^{8}$ and comisariado, according to interviews, were paid millions of pesos by the wind company to facilitate the arrival of the project (see also Howe et al. 2015). Charis Ejidatario received 40,000 pesos (US\$2,247.41) and Zapata Ejidatario received 18,000 pesos (US\$1,038). ${ }^{9}$ According to one fisherman, when Mareña Renovables entered the area in 2011 "they just wanted to tour the Barra", offering to pay people 2,000 pesos (US\$115) a day and 100 litres of gasoline. ${ }^{10}$ The offer was attractive and since people did not know that Mareña "wanted to kick us out of this town," they accepted the work. ${ }^{11}$ The town is dependent on fishing, farming, the salt refinery; producing crafts for tourist areas as well as seasonal work-related out-migration (see Stephen 2007). While locals with boats began measuring the depth of the Lagoon for the wind company, others cleared and improved the roads (to move in heavy machinery) ${ }^{12}$ and started digging and measuring the depth of the fresh water under the Barra. "[Mareña] said to the people of Álvaro Obregón: 'We are going to pay you to check if there is fresh

\footnotetext{
${ }^{7}$ This is regarded as an insult and being spat in the face by the company.

${ }^{8}$ Confirming whether this was paid individually or collectively is difficult from the interviews, but according to one interviews specific COCEI politicians were paid anywhere from 15-125 million pesos.

${ }^{9}$ Interview 3.4CP, May 10, 2015.

${ }^{10}$ Interview, ibid.

${ }^{11}$ Interview, ibid.

12 This work was organized by the COCEI and workers had to hand over, in the words of one, their "voter IDs, everything," but they got paid very well. One worker got paid 1,200 pesos for two days work.
} 
water in the Barra'," recounted the fisherman "Leon", "we thought they were going to take a hand shovel and to dig in the sand to look for fresh water, but by the time we had realized what was happening this company had brought in a generator, they hired a tractor and brought in about forty $4 \times 4$ vehicles [...] and they brought several other machines." ${ }^{13}$ It became undeniably clear that the company was planning more than just tours and monitoring the Barra.

With the start of construction, fishermen began witnessing environmental and livelihood impacts. Leon explained that they drilled seventy meters deep in the Barra and from the very first time they began to do this work "the fish began to die." Another fisherman recounts:

[When Mareña Renovables] did testing, they pounded the ground and tons of fish died and went away. [....] Because of the noise and also the oil they were throwing into the sea.

AD: Oil?

Oil from the machinery.

AD: Did you see the oil in the sea?

Yes.

AD: Could you tell me more or less what you saw?

Well at that time tons of fish died - throughout the whole sea as far as that hill tons of fish died and went away. So when we went to fish, there was nothing to catch. Since they left and there is no more noise, the fish are back, now people are catching fish again.

AD: How long did it take for the fish to come back?

Like a year. Maybe they hid, maybe they went away, but tons died. ${ }^{14}$

This account was echoed frequently by older fishermen. Often accompanied by tears and intense emotions, they described the different types of fish that died first and how millions of fish were scattered across the Lagoon as far as the eye could see. Another fisherman equates the exploration phenomenon with an earthquake, "any kind of sound will scare them away—-the fish hear everything." ${ }^{15}$ Fish are vulnerable to habitat fragmentation, noise, vibrations and electro-magnetic interference from offshore wind energy construction and operation (Hawkins et al. 2014; Tabassum-Abbasi et al. 2014: 282-284), yet this remains an under-researched topic with a multiplicity of variables regarding environmental specificity, aquatic species and project impacts (Roberts and Elliott 2017). This environmental impact was combined with testimonies of people dumping oil and other chemicals into the ground. ${ }^{16}$ When the construction workers "changed the oil in the machinery", said the fisherman, "they just tossed it on the shore. So when it rained, it washed all the cans and oil into the sea. Then you could see all of that oil in the water"17 (see also Navarro and Bessi 2015). The ecological circumstances of the Barra are particularly unique, making the testimonies of these fishermen important contributions when considering the ecological impact of wind turbine construction on sand bars. Meanwhile, fishermen struggled when survey stakes cut their fishing nets. Thus began some of the first confrontations between construction workers and fishermen that would later escalate into insurrection and a struggle for autonomy against the wind company and their political affiliates.

The mass death of fish was a danger to the town and to livelihoods. This threat to livelihoods coincided with three other issues characteristic of ecological distribution conflicts (Martínez-Alier 2002; Zografos and Martínez-Alier 2009):

\footnotetext{
${ }^{13}$ Interview, ibid.

${ }^{14}$ Interview 3.13, May 11, 2015.

${ }^{15}$ Interview 3.16, May 11, 2015.

${ }^{16}$ Constructing wind turbines on sand, vegetation and fresh water, requires putting solidifying agents in the concrete. A farmer outside Juchitán described it: "they brought some fluids and they poured them into the water and I do not know what happened, but after that the water stopped. "

${ }^{17}$ Interview 3.13, May 11, 2015.
} 
- unequal access to decision-making and information;

- unequal distribution of benefits, following a divide-and-rule logic;

- and law enforcement practices.

First, the town of Álvaro Obregón was never consulted. "They entered in a sneaky way", said "Joker", "they did not do a citizen consultation. They went directly to the political leaders, the ejido comisariados, passing out a lot of money—offering millions of pesos." ${ }^{18}$ Guided by local politicians, Mareña Renovables only consulted the ejidos and land owners, placing the fate of the town with a population of 3,558 into the hands of approximately 200 people $^{19}$ (SEDESOL 2010). Likewise, specific information about benefit sharing and environmental impact was also withheld from the town and ejidatarios (Howe et al. 2015). Second was the unequal pay between Ejido Charis and Zapata-40,000 and 18,000 pesos, respectively. There were also different payments for people who previously sold their land, who received 20,000 pesos in Ejido Charis and 25 in Ejido Zapata that did not receive money, becoming the first to blockade and protest the wind company. ${ }^{20}$ Said differently, Mareña Renovables was engaged in "adverse incorporation" of locals into project preparation, information and benefit sharing (Hall et al. 2015: 474). Third is the arrival of law-enforcement practices to the Barra. Mareña Renovables placed a chain across the road to the Barra, hired security guards to protect the construction site, imposed regulations around fishing times and required identification cards. This was reminiscent of the 1960-70s when Federico Rasgado imposed controls over the land purchased from Charis's daughter and gained the support of the Assembly of Indigenous Peoples of the Isthmus of Tehuantepec in Defense of Land and Territory (APIDTT), eventually triggering a popular uprising against the Mareña Renovables project.

\section{4. "We are the sea": battle for the Barra}

Mareña Renovables blocked the entrance of the Barra and subjected the fishermen to police controls. Fisherman "El Vato" recounts:

The people wanted to go fish and the state police had a chain blocking [the entrance] and they started asking people: 'Where are you going and when are you coming back?' This one fisherman asked them back: 'Who are you to ask these questions? We have been living here a long time.' They replied: 'There is an order here that says you have to tell us when you are going and coming back and that you are not allowed to stay past that departure [time].' So that guy did not say anything else, he just returned back and told people and people waited to see what the Mareña Company's next move was. ${ }^{21}$

The "chain" is frequently recounted in all of its symbolism as the final trigger for the uprising. Explaining the significance of this imposition, the elder "Wild Cat" explains: "Right now we have the freedom to go [to the Laguna] whenever we want. We could go at midnight, at sundown or at sun up-anytime we are free because we do not have a commitment to anybody but ourselves." ${ }^{22}$ Taking great pride in the communal land and the freedom it garnishes, people pray, socialize and fish at anytime from the Barra. It is the village norm to fish between two and seven in the morning, not only in accordance with tide and fish cycles, but also to catch the bus at six in the morning to sell fish at the Juchitán market.

One Ejidataro recounts the reaction from people when they found out Mareña Renovables was going to build on the Barra:

\footnotetext{
${ }^{18}$ Interview 3.5, May 9, 2015.

${ }^{19}$ Interview 3.4CP, May 10, 2015.

${ }^{20}$ Interview Ibid.

${ }^{21}$ Interview 3.2CP, May 9, 2015.

${ }^{22}$ Interview 3.3, May 9, 2015.
} 
That is when the announcement was made to go yell at the comisiarado: 'Did you sell the sea!?' He said: 'No, no one told me that it was going to be on the sea.' And the people said to him: 'We are sorry Margarito, if the companies take over the sea and prohibit us from fishing we are going to kill you.' He said: 'No, but they did not tell me.'23

In the meantime, state police moved in and arrested some farmers and fishermen in the vicinity, which was relayed by word of mouth and a loudspeaker. A woman recounts a loudspeaker announcement and the subsequent reactions: "'The people that had their relatives working out on the field, they need your help, they have just been kidnapped!' They [the people] grabbed their machetes, sticks and their sling shots"24 and eventually "when that happened people detained the two comisiariados and their children and the people said [to the police]: 'If you release the people that you have, we will release the comisiariados. If you don't we will kill the comisiariados'." 25 The exchange was made, but the seeds of conflict were in place. The first skirmishes with state police began in October 2012 and lasted until the Battle of the Barra on 2 February 2013. People went to the Barra and began attacking security guards and wind company equipment and formed a barricade to prevent the project. The barricade was formed in the abandoned house of General Charis (Figure 2). Determined, "people said they would all be willing to die before allowing the company to go pass the barricade," recounts the captain of the polícia comunitaria. Summarizing earlier police interventions, he continues: "the company tried to enter with fifteen police patrols full of state police, they couldn't and they tried again, this time with twenty-five police patrols. Then they tried again with more than fifty patrols and they couldn't." 26

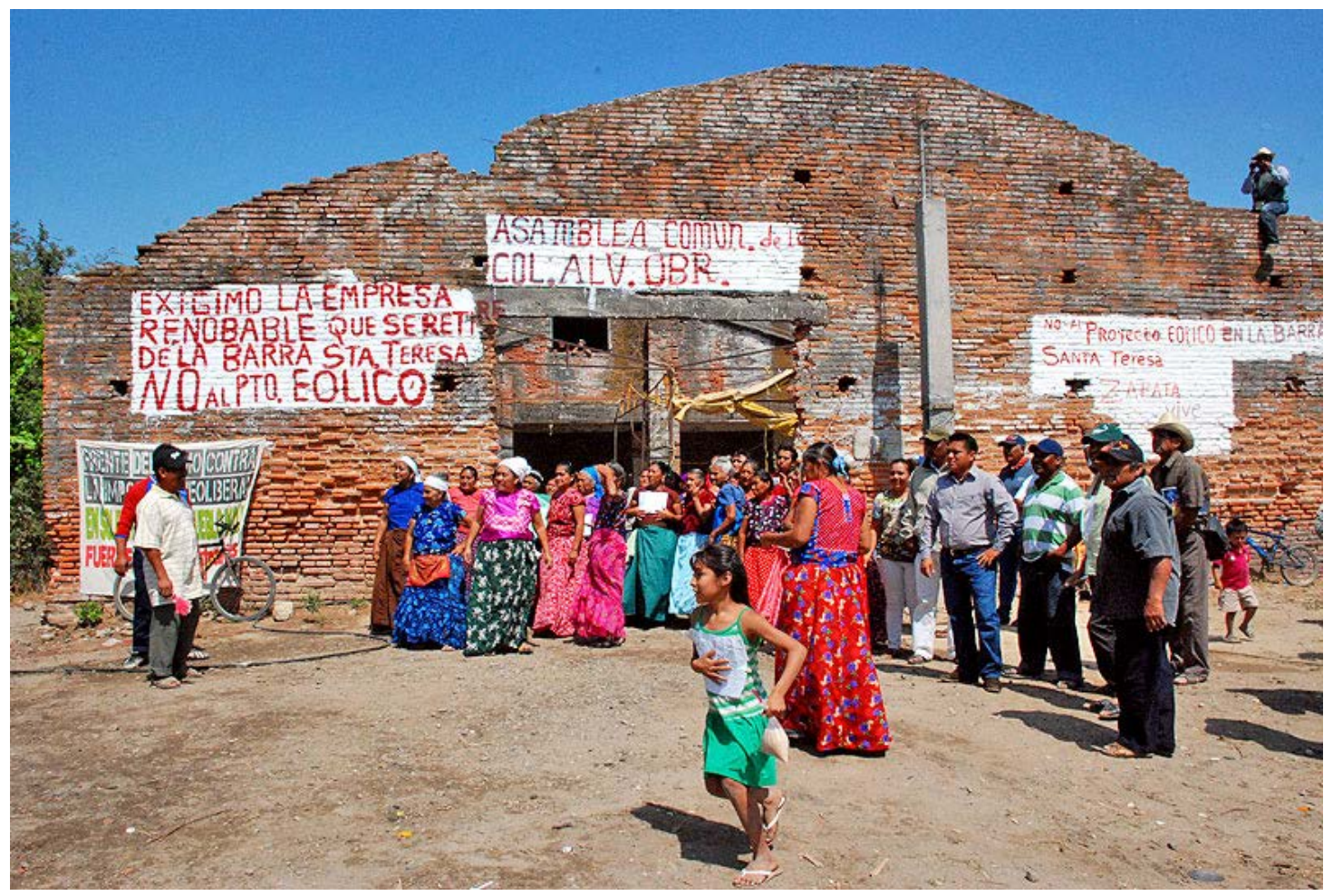

Figure 2: The Communitarian headquarters, 2013. Source: dorsetchiapassolidarit. ${ }^{27}$

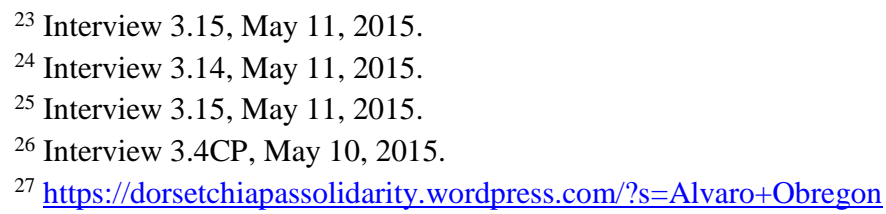


On 2 February 2013 at $8 a m$ in the morning, the police tried again. ${ }^{28}$ Attempting to flank the barricade, roughly 500 state police came in from the north near Ejido Zapata, while another regiment came from the east near the cemetery and the Laguna. Learning from previous battles, the police entered the town on foot, shooting their guns into the air and ground.

When the police moved into town the people realized "they were surrounded, but were already prepared with their slingshots", said El Vato, ${ }^{29}$ while the Dragon remembers at the barricade:

I said: 'compañerxs, now is the time to start the war.' [....] And everyone said: 'I will!' Not ten, twenty, or thirty people, everyone said they were going to war. [....] [M]y compañarxs were throwing rocks and I was shooting fireworks and we chased them away from the five hundred meters where we started, we defeated them, pushed them away - away from there. And we came back and took the other road to the cemetery where the other contingent was, they were all on the beach, but they wanted to come back to the cemetery, but we had another barricade in the cemetery. ${ }^{30}$

"Tortuga," fighting on the beach near the cemetery recounts a similar message:

We have to fucking fight-fight time. We cracked some of the state police skulls. They got a good beating, like this-bam! And all the stones thrown and shot, we ran out of stones and on the beach we started using the shells with sharp edges, but we used everything against them. I grabbed the shell, even with the sand in it and I would shoot it at them-boom! I would grab the sharp edge and it would cut me, but I did not care. I was just making mayhem—Boom! Boom! Boom! ${ }^{31}$

The people of Álvaro Obregón organized and rose up to defend the sea, which "Tank" described was won by "using fishermen wisdom, we started to move just like when we are fishing and started to surround the police. It's important the fishermen wisdom, and with slingshots we made them run because they knew that we had them." 32 Fishermen wisdom and decades of social protest as members of the COCEI was undoubtedly influential in the battle. Afterwards, the town formed a Communitarian police (polícia comunitaria) and the Community Council (cabildo comunitario), known together as the Communitarians. The Communitarians realized that if the Barra was to be saved, their struggle had to extend to be against all political parties. They came to form their own political authority in the town as a reaction to the wind energy project.

\section{The Communitarian struggle}

Oaxaca is unique compared to other Mexican states in its recognition of Indigenous customary lawusos y costumbres. Related to pre-colonial recognition that Indigenous people had localized forms of governance and justice, usos y costumbres is a form of Indigenous governance that literally translates as practices and customs (Stephen 2005). In the early 1990s, the Oaxacan constitution changed Article 16 to recognize the 16 different ethnic groups in the state and Article 25, which established "respect for the traditions and democratic practices of indigenous communities" (Stephen 2013: 69). Then on 21 March 1994, the state government announced the New Agreement for Indigenous Peoples (Nuevo Acuerdo para los Pueblos Indíenas), which recognized usos y costumbres and advanced the rights of Indigenous people in three areas:

\footnotetext{
${ }^{28}$ Visuals: https://www.youtube.com/watch?v=IyETkKlJ54w ; https://www.youtube.com/watch?v=oFszED7ECs8

${ }^{29}$ Interview, 3.2CP, May 9, 2015.

${ }^{30}$ Interview 3.3CP, May 10, 2015.

${ }^{31}$ Interview 3.7CP, May 11, 2015.

${ }^{32}$ Interview FN-B1, February 16, 2015.
} 
(1) the administration of justice,

(2) resolution of agrarian conflict, and

(3) respect for customs and traditions (Stephen 2013).

This creation of political space for Indigenous self-governance in Oaxaca appears to have been influential in the Communitarians' next move.

On 8 December 2013, the Communitarians peacefully took over the Álvaro Obregón town hall (APIIDTT 2014). The Communitarians decided that they were not going to let "the politicians give orders here anymore- it is time for us to give the orders." ${ }^{33}$ The takeover began with over 1,000 people marching from the General Charis barricade to the town hall. "[T]he Polícia Comunitaria led the way followed by the [Communitarian] mayor with his council," recounts El Vato who continues to explain how:

...we walked over here and we stopped before we got to the town hall [in the town square]. There were police guarding the town hall and we talked to them and we said: 'You know what? We are going to be taking on this work guarding this building now. We think that your year of service has now ended. You should just step aside and let us takeover.' And they said: 'That is fine we are leaving.' They grabbed their stuff and they left and we stayed here. [We asked each other:] 'Now what do we do? What about the [police] patrol vehicles? Let's go talk to the [former] mayor Ricardo and ask him to turn the vehicles over to us officially and voluntarily and also the ambulance and everything else. Okay, let's go.' Some of the folks went in like a delegation and when they talked to him, right then he created a document and signed it, turning over the vehicles voluntarily. So the new [Communitarian] mayor came in and started to work. ${ }^{34}$

The Communitarians took over the town hall, establishing usos y costumbres, which attempted to form a type of comunalidad (Luna 2010; Manzo 2011). This governance system is designed around civil cargos (community public duty), mayordomías (religious cargos/communal festivals), tequio (communal work obligations) and cooperación (collective pooling of resources for public works) (Stephen 2005). Among the civil cargo is the topilillo or police, where here the polícia comunitaria serves a similar function following this tradition of communal services without pay. Townships recognized as usos y costumbres still have the possibility of receiving state funds, which is another issue underlining this ecological distribution conflict in Álvaro Obregón. Currently, the communitarians are in a legal battle for Indigenous recognition led by Bettina Cruz of the APIIDTT before the Inter-American Commission on Human Rights, which would legitimize their autonomy and provide access to state funds. ${ }^{35}$

The town hall takeover forced the former municipal leaders into their homes. The ex-town officials were associated with the Juchitán government (held by the PRD-COCEI), political elites and backed by Mareña Renovables/Eólica del Sur. Then the previous municipal leaders, with material support from the Juchitán regime, formed the Constitutionalists faction—commonly known as Los Contras (The Enemy/cons). The Constitutionalists are the politicians who have created a counter-town hall and counter-police force in reaction to the Communitarians takeover, seeking to re-establish the political process-voting-according to the Mexican constitution. The Communitarians refuse elections as they see the political process as completely rotten. Elaborating on this point, Pablo states: "The political parties have corrupted the communities, take advantage of the peoples' lack of knowledge and hand out miserable things: food baskets, machetes, sandals, hats and in this way they have gotten people in Álvaro Obregón to vote." ${ }^{36}$ Politicians according to the Communitarians are filling their pockets with money, buying votes and legitimizing the construction of the Mareña project or other future wind projects on the Barra. Álvaro Obregón represents an Indigenous

\footnotetext{
${ }^{33}$ Interview 3.7CP, May 11, 2015.

${ }^{34}$ Interview ibid.

${ }^{35}$ Filed by the Independent Investigation and Inquiry Mechanism (MICI) of the Inter-American Development Bank.

${ }^{36}$ Interview 3.9CP, May 17, 2015.
} 
"environmentalism of the poor" (Martínez-Alier 2002), which extends to struggle for Indigenous selfgovernance and autonomy.

\section{Motives for mobilization}

A Communitarian asks: "if you take the sea, then how are people going to live?" ${ }^{37}$ Resistance against wind energy emerges from threatened livelihoods as well as generational commitment to land and sea. "I am fighting for my people, for our sea, our land, our children, grandchildren and future generations," said the Communitarian "Mapache", "the people do not realize they are accepting money from the wind energy company in exchange for losing their inheritance they would leave to their children and grandchildren." ${ }^{38}$ The people of Álvaro Obregón felt compelled to defend their land, sea and cultural integrity for the next generations to be ble to live dignified Zapotec lives. "Compañarx to tell you the truth, we are watching over the sea and the territory of Álvaro Obregón - look at this beautiful wind, lots of birds singing all the time and the mangos", says "Big Bear":

See we are going to lose these animals and we do not know what else, why are they [Mareña] going to do this? Over there [in the cities], you have to pay for light, water; you have to pay for everything and you are going to have to work like a slave to earn 2,000 pesos and you pay 2,000 for rent for one month, how are you going to eat? Then 600 pesos for water and then the next week you have to pay 600 pesos for light, and then you will pay 800 pesos for eating for one or two weeks-I have already been there and I have seen it. ${ }^{39}$

This fight against the wind energy is not only about preserving the beauty and cultural life connected to the land, but also fending off a "modernization" that places them in a greater position of dependence and subjugation to the Mexican political economy. The Communitarians are not against development or progress, but a development that will degrade the sea, threaten their livelihoods and place their existence in the hands of transnational wind companies or further into the pockets of local/national politicians.

Furthermore, the Communitarians are not against wind energy as such, but the location, quantity, size and how the energy is used-exporting energy generated from "their winds" and communal lands to transnational companies and industrial centers in Mexico in no way reflects a communal "good." This is not only ecologically destructive and constituting a "center-periphery" conflict dynamic (Zografos and MartínezAlier 2009: 1741), but it is potentially genocidal considering how the wind megaproject can irreparably alter or destroy both the material and spiritual sustenance of Zapotec and Ikoot populations (see Toledo 2015; Dunlap 2018). The Communitarians can agree to development, but only if the land and the entire community are respected-not irreparably damaged and affecting their ability to subsist (Dunlap 2018). Politicians and transnational capital appear as substantial barriers for Álvaro Obregón's self-determination and autonomy, serving to widen existing social divisions, and potentially exacerbating political corruption and ecological destruction. "Government welfare programs are like fishing, they put out bait for people to grab thinking it's food, but it is always to fuck them over," explains "Stash." "The government will never lose when they give you money." 40

The Communitarians have roughly three overlapping factions within their group. First, "radicals" who want to protect the land and sea and rid the Constitutionalists from the village- "We need to break each one down until they are destroyed", says the Dragon, "[s]o the town can be completely free of politicians, foreigners and the big companies that do not want to pay and come in[to the town] right."41 Second, "moderate" Communitarians want to reform the division between Constitutionalists and Communitarians-destroying the

\footnotetext{
${ }^{37}$ Interview 3.22, May 12, 2015.

${ }^{38}$ Interview 3.10, May 10, 2015.

${ }^{39}$ Interview 3.22, May 12, 2015.

40 Interview FN-B5, May 8, 2015.

${ }^{41}$ Interview 3.4CP, May 10, 2015.
} 
Constitutionalists "is not that easy because we are all the same family and we are from the same town", says Stash. ${ }^{42}$ Third, "instrumentalists" that seek to fight as a means to acquire more funds and social development through new contracts with the wind company and/or politicians. Likewise, there are two noticeable "neutral" positions articulated in the interviews conducted within the town. Their holders argue they want the land and sea to remain protected, but feel they are stuck between two "gangs"-Constitutionalists and Communitarianswho fight to control the village. ${ }^{43}$ This sentiment emerges from the general combativeness of the polícia comunitaria, mixed with pre-existing personal conflicts as well as alcohol and marijuana consumption that violates existing moral sensibilities. A second neutral position favors the wind project, but is critical of the benefit sharing, social development and the systemic political corruption in the town. This leads people of this persuasion to criticize the Communitarians for not voting and participating in formal elections and the Constitutionalists as "selfish" and "corrupt" politicians. ${ }^{44}$

\section{The counter-organization: Constitutionalists}

The divide and social rupture created by the Mareña wind project has led to a kind of low-intensity civil war in Álvaro Obregón between the Communitarians and the Constitutionalists. While extreme political violence is infrequent, there a permanent social tension, and a repressive strategy to undermine civil or insurgent opposition. In Low intensity operations, ${ }^{45}$ Brigadier General Kitson (2010 [1971]: 79) advocates for "counter organization", defined as a "method by which the government can build up its control of the population and frustrate the enemy's efforts at doing so." The perspective of counter-organization in the struggle for governmental legitimacy is insightful for understanding the counter-insurrectionary reaction of the Juchitán regime and local elites (Dunlap 2017a). Concession and coercion are crucial instruments in such counterorganization. Coercion manifests in Álvaro Obregón with the Constitutionalists counter-police force, while concession emerges with distribution of funds to clients, and promises of jobs and town-wide social development. Both of these are intended to stifle and de-legitimize the Communitarians as they compete for legitimacy. The Constitutionalists counter-organization performs a number of activities to assert its presence.

"The Contras are the politicians", explains a Communitarian. When it is time for elections in Álvaro Obregón the politicians go door-to-door, holding rallies and distributing food baskets as well as paying "people two-thousand, three-thousand pesos for their vote"46 -handing over their voter identification and personal information. Rooted in family and patronage networks, the Constitutionalists politicians create a political cadre by providing promises and money to the town. When Mareña, among other wind companies, came to the Istmo, this appeared as a lucrative career opportunity for politicians. An ex-COCEI militant, Mapache, commenting on a key COCEI politician, explains: "Now that there is nothing left to grab, he has come here to take our lands from us and sell it. That is how we started to rise up against him, because he has become so powerful, and now he is crushing indigenous people." 47 The conflict in Álvaro Obregón is centered largely on political control, which is related to respect, livelihoods and the wind company's distribution of millions of pesos.

While building on the historical PRI-COCEI divide, the wind energy issue also transcends this division. It appears that Mareña entered with money and the politicians were quick to negotiate with them, assuming the loyalty of Álvaro Obregón, the politicians would become the company's proxy force in the town, first to ensure the smooth construction of the project and, later, to regain control of the town with other political parties (see below). Identifying as neutral, a teacher impersonates Mareña discourse to the local politicians: "Hey, I already paid you to put your people in line; it's your people." ${ }^{48}$ The political parties, notably the COCEI because of their history in the town, acted as intermediaries, managing a type of "decentralized household rule" and, later, with

42 Interview 3.9, May 10, 2015.

${ }^{43}$ Interviews 3.17, 3.18, 3.19 \& field notes (FN).

${ }^{44}$ Example Interviews 3.1, 3.2, 3.6 \& FN.

${ }^{45}$ These are techniques with long precedents in Mexico (Dunlap, 2017a).

${ }^{46}$ Interview 3.10, May 10, 2015.

${ }^{47}$ Interview ibid.

${ }^{48}$ Interview 3.2, May 8, 2015. 
the Constitutionalists attempts to continue this rule by maintaining a permanent presence in the town (Owens 2015: 8). Said differently, the COCEI-PRD, with selective assistance from the PRI, is funding a proxy force to counter and domesticate local resistance to the Mareña project.

The Constitutionalist organization is comprised of roughly four overlapping types of personnel that make up their loose knit counter-organization. The first believe in modernization, hoping the wind project will fulfill their dreams of progress through job creation, social development and individual prosperity. Second are fishermen and farmers who want jobs to feed their families and improve their lives and are willing to work with the Constitutionalist police, as long as they are not forced to shoot their neighbors. Third are political party militants, taking the ideology of their political parties to heart. Fourth are mercenaries/gunmen who are hired to transform and, at times, participate in this counter-organization to forge a trained police and/or mercenary force. ${ }^{49}$ The majority of Constitutionalists, however, remain in the first and second category. A Constitutionalist in the first category, typically younger, is bored of the traditional lifestyle, arguing that: (1) the fish population is declining and (2) the majority of the income from the town comes from seasonal migrant labor within and outside the region (Huatulco, Cabo San Lucus, Loretta, Monterey and the United States). To them, this justifies wind park construction and the consequent ecological impacts, as the sea does not produce the livelihood desired. ${ }^{50}$ The arrival of this perspective, the Communitarians tell me, is a product of state school becoming mandatory in the area, which some hold responsible for the cultural change the area has experienced. ${ }^{51}$

Regarding the second category, a person who had a one-year contract with the Constitutionalist police describes their motivations:

I was working for them because I have a family to feed and they were paying me. [...] I have worked with them because they paid me to help maintain my family, but the reality here is that everyone from here is like brothers and sisters and what is the point if I run into somebody and we fight? The politicians will just be standing off to the side and watching us fight—-this makes no sense. ${ }^{52}$

Many people associated with the Constitutionalist faction are not necessarily in favor of building on the Barra, but enjoy the well-paid work the Constitutionalists and the company offered. This perspective retains a level of indifference to the political factions, while others in this category value the Barra, but hold vendettas against individuals or families associated with the Communitarians. Notably, the Constitutionalist above was quick to emphasize the combative attitude of the polícia comunitaria and their propensity to drink and smoke marijuana.

The third category is associated with political party loyalty, especially with the COCEI who were seen as defenders of "the people" with great success during the 1970s-1990s. People maintain loyalty, trust and commitment to decisions of the party and their leaders. This loyalty is cemented by continuous access to jobs, welfare benefits, food handout, payments and generational family ties to their respective parties. This is not strictly related to the COCEI, but also the PRI and others in the town in agreement to collaborate with the wind companies. Political loyalties, among the other (blurry) analytical categories undoubtedly overlap.

The Istmo in general, and the Seventh Section neighborhood of Juchitán in particular, have a reputation for gunmen families, which elites and politicians have used to organize hit squads in Oaxaca (Dunlap 2017a). The fourth category involves these gunmen and other professionals trained in dispensing violence scientifically. In Álvaro Obregón it has been reported that extra-judicial gunmen from outside and inside the town operate in the service of the political parties with relationships with transnational criminal organizations (see Paley 2014; Correra-Cabrera 2017), which, consequently, is indirectly supporting the wind companies in the region.

\footnotetext{
49 The line between police and mercenaries becomes a thin line revolving around legacy, political processes, training and personal perspective.

${ }^{50}$ I was told repeatedly that this is a rehearsed Constitutionalist party line.

${ }^{51}$ For a conversation on cultural change through schooling in Oaxaca see Meyer and Alvarado (2010).

52 Interview 3.20, May 11, 2015.
} 
Notably, local politicians are responsible for managing, stabilizing and securing the area for wind energy development (Dunlap 2017a). It is also rumored that an expert in policing (and counterinsurgency) ${ }^{53}$ has been hired by the Juchitán administration to train the Constitutionalist police. Explaining repression in town, "Flower" says, "the Contras from other places are setting fire to people's houses. They are burning [fishing] nets of poor fishermen because we don't have money and they do." ${ }^{54}$ Nevertheless, a good number of research participants were confident that the majority of the Constitutionalists were more along the lines of the first two factions. Likewise, many Communitarians were convinced, based on the Battle for the Barra and their love of the sea that if Mareña Renovables/Eóica del Sur or any other wind company tried to enter the town again the majority of the Constitutionalist would rise up with the residents.

\section{Communitarian-Constitutionalist conflict}

Eventually, I began asking people in the town where the majority of support resides-with Constitutionalists or Communitarians? The answers asserted unanimously that it was the Communitarians, with one woman going so far as to claim that they have reduced crime and made the town safer. If this is true, this is similar to Sierra's findings in Guerrero (2005), where the polícia comunitaria is creating safer spaces and widens realms of participation for women. While patriarchal relationships are still a problem in the area, the high level of support and popularity for the Communitarians undoubtedly comes from their defense of the land, sea and culture in the face of coercive development. The dynamic in Álvaro Obregón, however, has resulted in something akin to a low-intensity civil war, as argued above. Filled with tension, the two factions patrol the town with their shotguns and M-1 carbine rifles, and resort to screaming threats and fighting with fists, sticks, machetes and sling shots. These are common, while the use of firearms is less frequent. The lower manifestation of this tension, a woman explains, is neighbors "saying nasty things to us, saying he was going to come into our house and every time we walked by he yelled and threw stones at us." 55 The occasional high-intensity events are generally around election time, as demonstrated by the events in March 2014.

The Mayor of Juchitán Saúl Vicente Vázquez announced elections would be held in Álvaro Obregón on 2 March 2014. ${ }^{56}$ To resist the elections, the Communitarians began patrols at six in the morning on the same day to keep out the state police and representatives of the National Electoral Institute (INE). This resulted in some high-speed chases, arguments and sling shot attacks to keep them from entering the town, which lasted until about eleven in the morning. Then the Communitarians regrouped with a big party at the town hall complete with food (Figure 3), large piles of rocks, and women grouped together in local dress holding enormous sticks ready for battle (Figure 4). Anticipating confrontation, waiting took on festive qualities. Meanwhile, the Constitutionalistists were holding elections on the other side of town in the house of a local political candidate with members of various political parties. Then, around two in the afternoon, a group of Constitutionalists and gunmen came out of the house and began attacking the Communitarians with bullets, stones and sticks to try and take back the town hall (APIIDTT 2014). This erupted into an intense battle, with rocks falling like rain, western-style shoot-outs and barricade fighting in the streets. One person from outside the town, there in solidarity, recounts fighting with the Communitarians:

I was running down that street going to the entrance of the town. The entire way along there were people yelling, rocks falling, glass breaking, a lot of screaming-it was a very loud situation. When I ran to the front line I suddenly heard-'POW! POW! POW!' I was like: 'FUCK!?' I turned my head up and there was a compa[ñarx] on the roof of the town hall with a 22 [rifle]—'click, click. POW! Click, click. POW!'-and I turned to my slingshot and I was like, 'fuck' and kept running. So when I was heading to the frontline the whole line of compas broke, they ran into

\footnotetext{
53 See Nomad (2016) for a discussion of Policing and Counterinsurgency.

${ }^{54}$ Interview 3.21, May 11, 2015.

${ }^{55}$ Interview 3.12, May 11, 2015.

56The film, Istmeño, viento de rebeldía by Aléssi dell’Umbria is comprehensive and briefly documents this battle at the end of the film.
} 
the walls because there was shooting from the other side also-'POW! POW! POW! POW!' I was like: 'FUCK!' When I arrived I realized that my slingshot was not powerful enough because I was shooting them and I hit them, but they [the Communitarians] shot their slingshots, the people would fall. So I abandoned my slingshot and started picking up rocks with my hand and fighting. ${ }^{57}$

There were groups of people in the blocks surrounding the town hall fending off the Constitutionalists' attack. In a group of fifteen people, Tortuga attests that the Constitutionalists "would have killed us if we had been too stupid" and how:

Some of our compañarx's were hurt. I was too. I was also hurt because I was hit by a piece of cinderblock right about there [point to the back of his head] and I grabbed another stone and bent over and another piece of concrete hit me right in between the shoulder blades and I was falling down - for real. So I stood up and kept shooting stones. So we were all there and that is when El Vato covered me. So I could get into a house and I broke into the house. [....] [W]e went inside and they kept shooting stones at us, but since the window was wide we shot from there and they could not come any closer. [laughter]. We were in the window—BANG! BANG!-we were dropping them and making them look like idiots, that is when we fucked them over. ${ }^{58}$

The Communitarians held the town hall, ${ }^{59}$ but later that evening Constitutionalist forces broke into the house of the Communitarian police captain, pouring gasoline everywhere to burn it down (APIIDTT 2014). This resulted in another intense chase and battle, after the Communitarians countered the Constitutionalist's offensive.

After this battle a new phase of relative co-existence emerged between the Constitutionalists and Communitarians. Yelling threats, intimidation and beatings were not uncommon, but no town-wide civil conflict would erupt until 7 June 2015. In October 2015, the displaced Eóica del Sur project was again prohibited by a court injunction (amparo), terminating wind energy development in Juchitán Country (Sin-embargo 2015). Despite this legal ruling, the Barra is not in Juchitán County, which causes concern for the Communitarians. In the spring of 2015 the government was still building a road from Salina Cruz through San Pedro Huilotepec, past the ejidos and out to the Barra. "[T]hey started a month ago on April $8^{\text {th }}[\ldots]$, we went to a plot of land and we saw it", says an Ejidatario who continues that:

...they are clearing and bringing a lot of machinery and I work on that side [of the ejido]. There is also three police patrol vehicles protecting the area and they are not from here and they are well-armed — they are state police and they do not let anyone enter there. ${ }^{60}$

The wind company, "Big Bear" says, "are going to return in 2016 and we are waiting for them and we are going to fight them again." 61 While no wind companies returned in 2016, docks and a 300 meter drain construction began in the Lagoon near San Dionisio del Mar in 2017, resulting in people burning the equipment as they were convinced it was for wind parks on the Barra (Chaca 2017). Ejido Zapata and Charis accepted money wind company money, discussed above,] and Mareña Renovables/Eóica del Sur has a thirty-year contract with three automatic twenty-five year renewals that is keeping the "triangle of resistance" on edge.

\footnotetext{
${ }^{57}$ Interview 3.8CP, May 13, 2015.

58 Interview 3.7CP, May 11, 2015.

59 For more accounts go to the APIIDTT Blog entries from 2012-2014.

${ }^{60}$ Interview 3.15, May 11, 2015.

${ }^{61}$ Interview 3.22, May 12, 2015.
} 


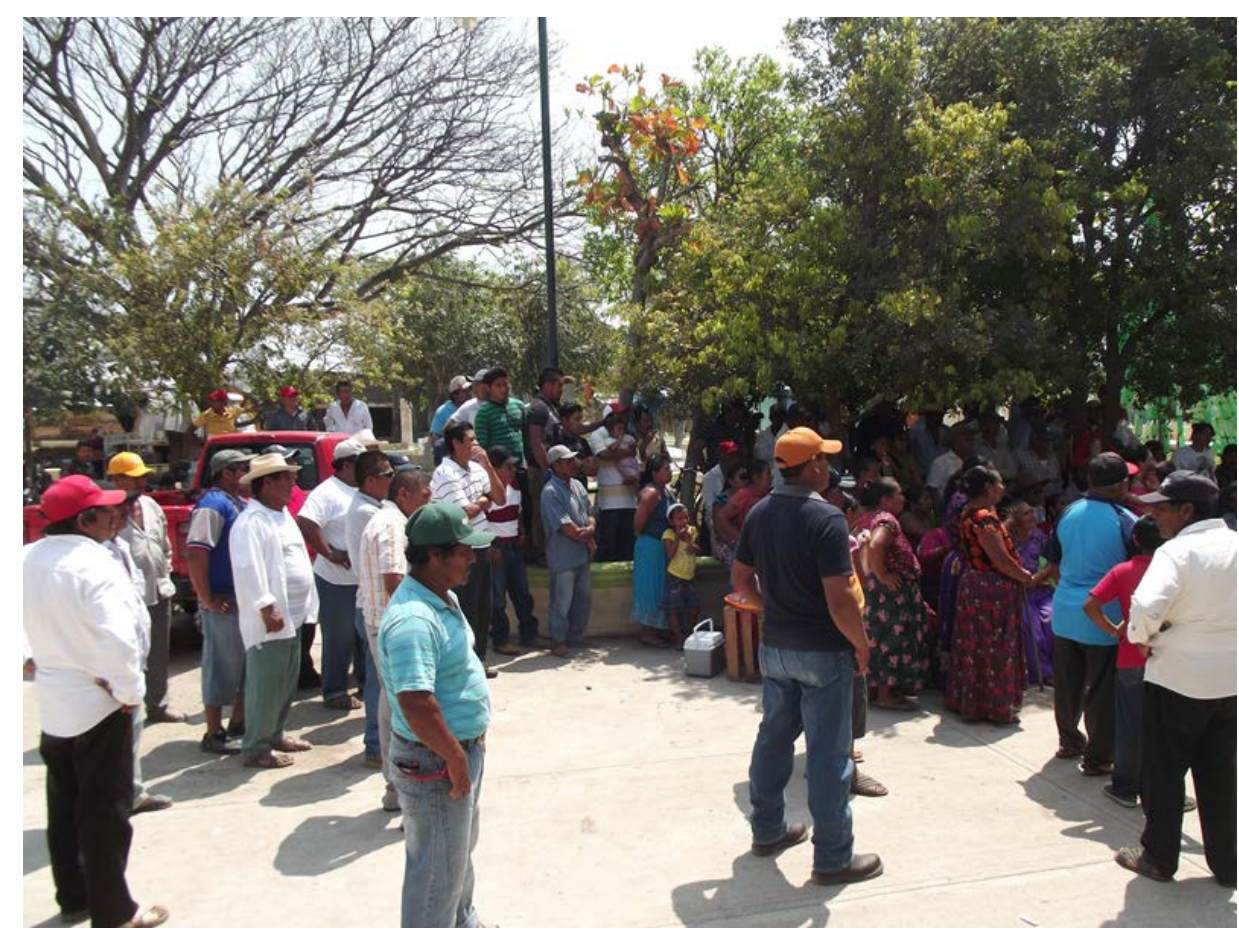

Figure 3: People prepare for battle in front of the Town Hall. Source: Sources: APIIDTT Mar. 2014.

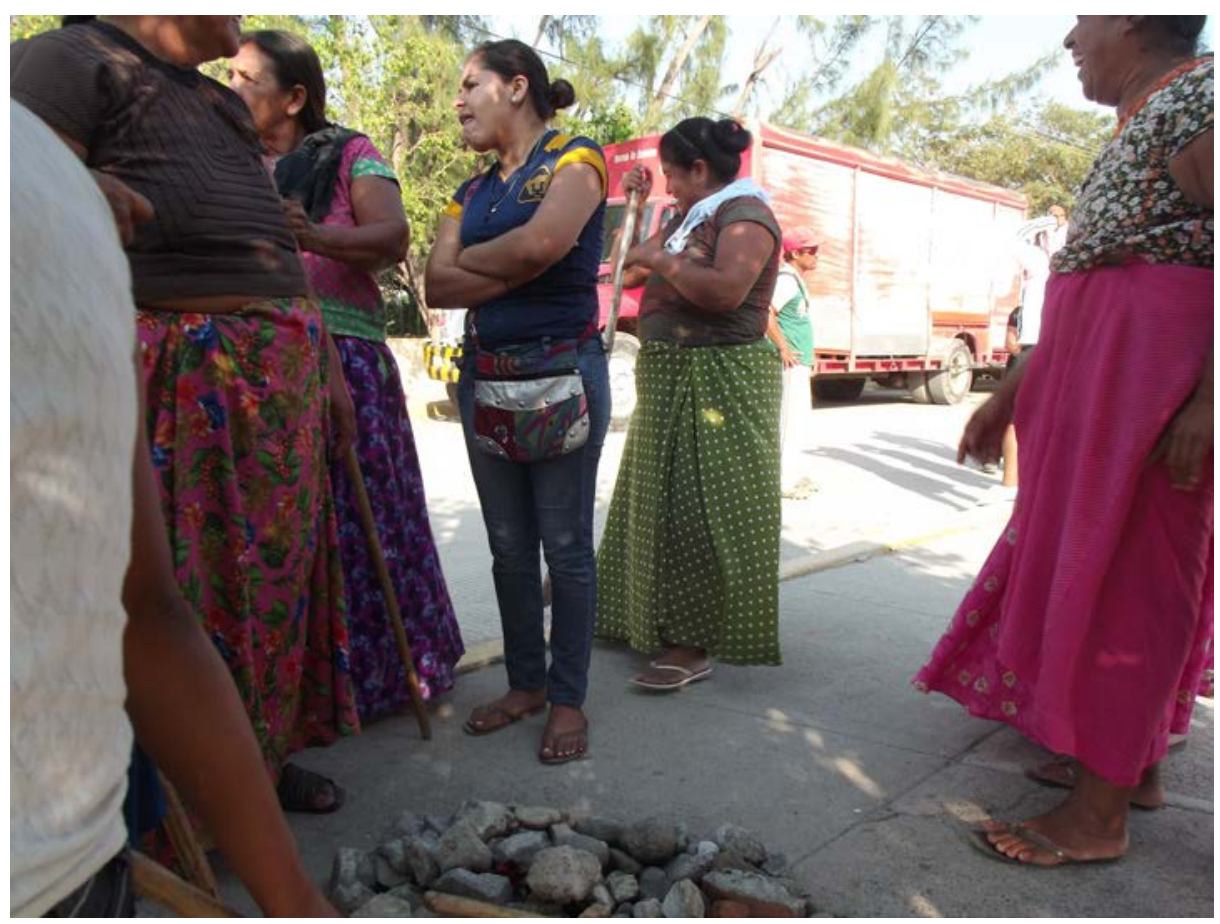

Figure 4: Woman stand with sticks, around pile of rocks. Sources: APIIDTT Mar. 2014. 
The Mexican government announced elections for 7 June 2015, and this was met with a boycott called by the seccón 22 teachers unions. This boycott was a response to economic privatization and the repressive Dirty War style conditions in the country (Correa-Cabrera 2017; Paley 2014, 2015), which manifested as demonstrations and blockades against gas stations, highways and government buildings (Matias 2015). This put the Mexican government on high alert, increasing the military, police and paramilitary ${ }^{62}$ presence around Juchitán and, consequently, escalating tensions in Álvaro Obregón where there are "threats from the electoral authority through the radio and in the newspaper saying that on the seventh the Mexican Army will be deployed to support the elections." ${ }^{63}$ It was around this time, that a person overseeing my research in Mexico received information that I was being targeted for an "assault and possibly fatal 'accident"', which was confirmed by people in the community. ${ }^{64}$ This was also matched by rumors spreading from the Salina Cruz court House that I was an undercover cop, while simultaneously I was being intimidated and attacked by Constitutionalist police. This led to the collective decision to leave on May 19, 2015. Then on 7 June another civil conflict broke out, not with a military siege, ${ }^{65}$ but with gunmen from Juchitán who were targeting outside supporters. ${ }^{66}$ This, I am told, resulted in another day of battle more intense than 2 March, where a total of ten people were shot, six of whom were from the Communitarians and three of which were in critical condition. ${ }^{67}$ Surprisingly, there were no deaths. After the December 2015 court injunction against Eólica del Sur, research participants explain that there was an increase in extra-judicial repression, now extending to robbing people while they are fishing. The 2015 court injunction continues to be contested, while the imposition of political parties in Álvaro Obregon has caused an escalation of violence. Again on May $14^{\text {th }}, 2016$ during a political campaign rally by candidate GloriaSanchez (PAN-PRD-COCEI) in Álvaro Obregón, conflict broke out between the PRI, the Constitutionalist and Communitarians, leaving one Constitutionalist police captain dead and more on both sides wounded (APIIDTT 2016; Gobierno 2016). This provocation by the political parties to impose elections in Álvaro Obregón has been condemned by the Zapatistas and the National Indigenous Congress (Imparcial 2016). The struggle against wind energy and for political autonomy in Álvaro Obregón continues with increasing violence, difficulty and uncertainty (Figure 5).

\section{Conclusion}

The level of conflict generated in Álvaro Obregón demonstrates not only the complexity of green grabbing, but also the propensity for climate change mitigation initiatives to provoke political violence. A textbook ecological distribution conflict was triggered in Álvaro Obregón, leading to militant resistance in in the name of land, sea and cultural dignity that has led to a tumultuous journey down the road of autonomy. The implementation of "sustainable", "clean" and "green" development projects is being implemented in nearly the exact same way as other fossil fuel, mineral and timber extraction projects (Brock and Dunlap 2018; MartínezAlier 2002; Nixon 2011). Political ecology shows us that industrial development—green or otherwise—require large tracts of land, which necessitates the invasion of areas for construction and resource capture that have significant livelihood and ecosystem impacts (Cavanagh and Benjaminsen 2017; Corson et al. 2013; Dunlap and Fairhead 2014; Fairhead et al. 2012).

\footnotetext{
62 I watched increases of unmarked trucks with heavily armed military and/or police personnel.

${ }^{63}$ Interview 3.9CP, May 17, 2015.

${ }^{64}$ Most of the people I was working with have been targeted by gunmen, state police or the military. Likewise, people resisting these projects have friends and family associated with the Constitutionalists, gunmen families and political parties, which allows for privileged information.

${ }^{65}$ A friend tells me the Navy was on the outskirts of town, and came to check on the town, telling people to call them when there are dead bodies to pick up.

${ }^{66}$ I suspect this was to minimize blood feuds between families in the town.

67 This is the only public source, which according to my sources is an underestimation of the wounded: http://kaosenlared.net/mexico-atacan-a-balazos-a-la-comunidad-guixhiro-alvaro-obregon-juchitan-oaxaca/
} 


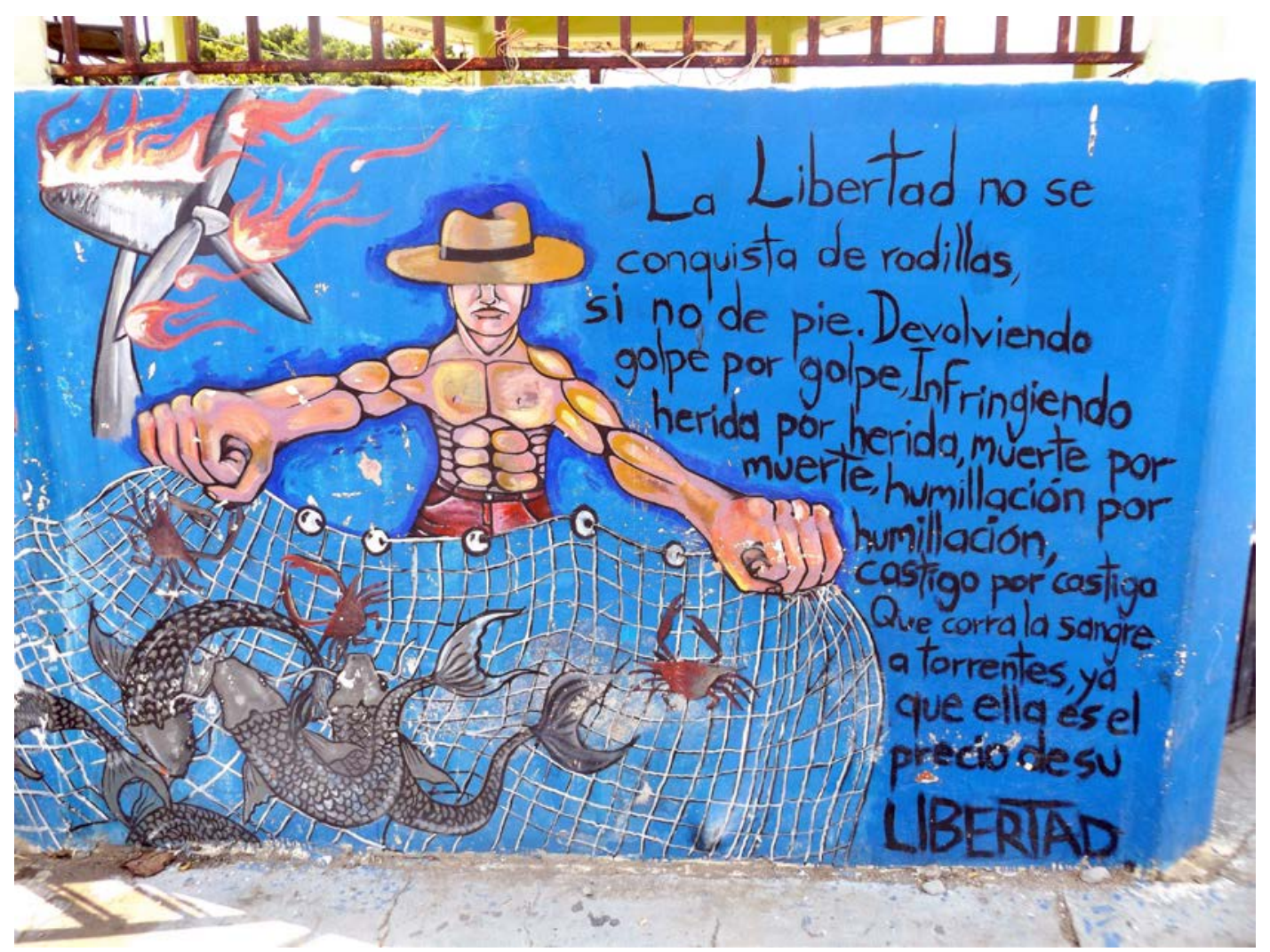

Figure 5: Town Square Mural: "Freedom is not conquered on your knees, but standing on your feet. Giving back hit by hit, inflicting wound by wound, death by death, humiliation by humiliation, punishment by punishment. Let the blood flow in streams because that is the price of freedom." Source: Author.

Fundamental to investigating land/green grabbing projects is the collaboration from national and local authorities. Sustained investigation into local collaboration and group dynamics reveals that the political reactions "from below" are navigating the "political reactions 'from above"' (Geenen and Verweijen 2017: 2)— government policy, transnational companies and regional elites-that selectively and strategically offer "opportunities", concessions, and who dispense coercion. The micro-politics of governance reveals the relationships underlining land deals, their specific affinity to the state and their reliance on various forms of coercion, concession and/or deception to achieve the desired goals of resource control and concentration. In Álvaro Obregón, militant resistance exposed climate change mitigation as a tool of land acquisition and conflict. New wind resource valuations are reigniting ecological distribution conflicts and creating new green grabs on Indigenous territory that affirm inequality, degrades ecosystems, widens social divisions and creates conflict. Said differently, market-based climate change mitigation polices, supposedly designed toward reducing the impact of climate change, is promoting conflict, the marginalization of Indigenous groups and the further degradation of ecosystems.

Community wind park models, akin to the one advocated by Oceransky (2011), would have mitigated this level of political violence. This is apparent as unequal benefit sharing, issues of transparency, adverse inclusion and political corruption were central issues in Álvaro Obregón. Even if inclusionary measures were sufficient, however, the ecological issues associated with industrial-scale wind energy construction would remain potentially neglected. The Communitarians are creating openings and new possibly not only for selfrealization, but also alternative expressions of development, but these openings are subject to systematic attacks 
from the Constitutionalists and other forces seeking to subdue and force their participation into electoral politics and development-as-usual. Micro-wind energy projects directly tied, built and operated by the community seeking "energy autonomy", as opposed to industrial-scale community systems or "energy sovereignty" (AvilaCalero 2017: 994), might prove complementary to struggles working to retain political autonomy and selfdetermination, as in Álvaro Obregón. Additionally, sustaining autonomy might require radical recycling programs, reviving ecological farming techniques and producing products-from "natural" bowls to sling shots-to create self-led and ecologically self-sufficient development. Álvaro Obregón, like other autonomous region in resistance, has fought for their spaces and holds some of the greatest possibilities for ecological sustainability and political freedom (Brock and Dunlap 2018). This autonomous project, however, is still in process and under the constant stress of shootings, intimidation and other attacks that condition the struggle and serve as obstacles to realizing alternative cultural and ecological lives. Technical skill-sharing for energy production, permaculture and funding are foundational in these moments. Meanwhile, solidarity and actions are needed everywhere by everyone to affirm practices that challenge unequal, coercive and industrial-scale development projects that promote submission to neoliberal economies, climate and ecological crises, which ironically claim to be "solutions" to these very same problems.

\section{References}

Altamirano-Jiménez I. 2014. Indigenous encounters with neoliberalism. Vancouver: UBC Press.

Altamirano-Jiménez I. 2017. "The sea is our bread": Interrupting green neoliberalism in Mexico. Marine Policy 80: 28-34.

APIIDTT. 2012-2014. Assembly of Indigenous peoples of the Isthmus of Tehuantepec in Defense of Land and Territory (APIIDTT) Blog. Available at: https://tierrayterritorio.wordpress.com/category/comunicados/english/.

APIIDTT. 2014. Gunmen attack the assembly in Álvaro Obregón. Available at: http://elenemigocomun.net/2014/03/gunmen-alvaro-obregon/.

APIIDTT. 2016. Comunicado urgente: policia municipal de Juchitan ataca a balazos a companaros de las asambleas comunitaria de Alvaro Obregon. Available at: https://tierrayterritorio.wordpress.com/2016/05/15/comunicado-urgente-policia-municipal-de-juchitanataca-a-balazos-a-companeros-de-la-asamblea-comunitaria-de-alvaro-obregon/

Avila-Calero, S. 2017. Contesting energy transitions: wind power and conflicts in the Isthmus of Tehuantepec. Journal of Political Ecology 24: 993-1012.

Binford L. 1985. Political conflict and land tenure in the Mexican Isthmus of Tehuantepec. Journal of Latin American Studies 17: 179-200.

Borras S., C. Kay, S. Gómez, and J. Wilkinson. 2012. Land grabbing and global capitalist accumulation: key features in Latin America. Canadian Journal of Development Studies 33: 402-416.

Briseno P. 2016. Frustran extorsión a empresa española; le pedían $\$ 500$ mil. Available at: http://www.excelsior.com.mx/nacional/2016/09/24/1118725.

Brock A and Dunlap A. 2018. Normalising corporate counterinsurgency: engineering consent, managing resistance and greening destruction around the Hambach coal mine and beyond. Political Geography 62: 33-47.

Cavanagh C.J. and T.A. Benjaminsen. 2017. Political ecology, variegated green economies, and the foreclosure of alternative sustainabilities. Journal of Political Ecology 24: 200-341.

Campbell H. 1994. Zapotec renaissance, Albuquerque: University of New Mexico Press.

Chaca R. 2017. Queman maquinaria en San Dionisio del Mar, Oaxaca. Available at: http://www.eluniversal.com.mx/articulo/estados/2017/07/12/queman-maquinaria-en-san-dionisio-delmar-oaxaca\#.WWZW9DInpGc.facebook.

Correa-Cabrera G. 2017. Los Zetas Inc. criminal corporations, energy, and civil war in Mexico. Austin: University of Texas Press. 
Corson, C., K.I. MacDonald and B. Neimark. 2013. Grabbing "Green": markets, environmental governance and the materialization of natural capital. Human Geography 6: 1-15.

Dabelko, G.D., L.H. Risi, S. Null, M. Parker and R. Sticklor. 2013. Backdraft: the conflict potential of climate change adaptation and mitigation. Washington D.C.: Woodrow Wilson International Center for Scholars.

Dalby, S. 2013. Climate change: new dimensions of environmental security. The RUSI Journal 158: 34-43.

Dunlap, A. 2015. The coming elections in Mexico: an attack against Indigenous self-determination in Álvaro Obregón. Available at: http://www.counterpunch.org/2015/06/04/the-coming-elections-in-mexico

Dunlap, A. 2017a. Counterinsurgency for wind energy: the Bíi Hioxo wind park in Juchitán, Mexico. The Journal of Peasant Studies 45(3): 630-652.

Dunlap, A. 2017b. "The town is surrounded:" from climate concerns to life under wind turbines in La Ventosa, Mexico. Human Geography 10(2): 16-36.

Dunlap, A. 2017c. "A bureaucratic trap:" free, prior and informed consent (FPIC) and wind energy development in Juchitán, Mexico. Capitalism Nature Socialism in press.

Dunlap A. 2017d. Wind energy: toward a "sustainable violence" in Oaxaca, Mexico. NACLA 49: 483-488.

Dunlap, A. 2018. The "solution" is now the "problem:" wind energy, colonisation and the "genocide-ecocide nexus" in the Isthmus of Tehuantepec, Oaxaca. The International Journal of Human Rights 22(4): 550573

Dunlap, A. and J. Fairhead. 2014. The militarisation and marketisation of nature: an alternative lens to "ClimateConflict." Geopolitics 19: 937-961.

Friede, S. 2016. Enticed by the wind. Washington D.C.: Woodrow Wilson International Center for Scholars. Available at: https://www.wilsoncenter.org/sites/default/files/mi_151220_enticed_by_wind_v4.pdf

GLCC. 2012. The General Law on Climate Change Mexico. Available at: https://www.iea.org/media/workshops/2015/15thghgtradingworkshop/GeneralClimateChangeLaw_En glishversion.pdf.

Gobierno. 2016. Condena Gobierno de Oaxaca hechos violentos registrados en Juchitán. Available at: http://www.oaxaca.gob.mx/condena-gobierno-de-oaxaca-hechos-violentos-registrados-en-juchitan/.

Hall R, M. Edelman, S.M. Borras, I. Scoones, B. White and W. Wolford. 2015. Resistance, acquiescence or incorporation? Journal of Peasant Studies 42: 467-488.

Hawkins A.D., L. Roberts and S. Cheesman. 2014. Responses of free-living coastal pelagic fish to impulsive sounds. The Journal of the Acoustical Society of America 135: 3101-3116.

Howe, C. 2014. Anthropocenic ecoauthority: the winds of Oaxaca. Anthropological Quarterly 87: 381-404.

Howe, C. and Boyer D. 2015. Aeolian politics. Distinktion: Scandinavian Journal of Social Theory 16: 31-48.

Howe, C. D. Boyer and E. Barrera. 2015. Wind at the margins of the state: autonomy and renewable energy development in Southern Mexico. In J.-A. McNeish, A. Borchgrevink and O. Logan (eds.). Contested powers. London: Zed.

Imparcial. 2016. EZLN y CNI piden autonomía y condenan violencia en Álvaro Obregón. Available at: http://imparcialoaxaca.mx/istmo/ap0/ezln-y-cni-piden-autonomía-y-condenan-violencia-en-álvaroobregón.

Juárez-Hernández, S. and G. León. 2014. Wind energy in the Isthmus of Tehuantepec: development, actors and social opposition. Problemas del Desarrollo 45: 1-9.

Kitson, F. 2010 [1971]. Low intensity operations. London: Bloomsbury House.

LAFAERTE. 2008. Law for the development of renewable energy and energy transition financing, Mexican Government. Accessed 1/25/2016. https://www.iea.org/policiesandmeasures/renewableenergy/?country=Mexico

Luna J.M. 2010. The fourth principle. In Meyer, L. and B.M. Alvarado (eds.). New world of Indigenous resistance. San Francisco: City Lights Books. 
Manzo, C. 2011. Comunalidad, resistencia indígena y neocolonialismo en el Istmo de Tehuantepec, siglos XVIXXI. Mexico City: Ce-Acatl.

Martínez-Alier, J. 2002. The environmentalism of the poor. Northampton: Edward Elgar.

Matias, P. 2015. Un muerto y 440 incidentes enmarcaron elección en Oaxaca Available at: http://www.proceso.com.mx/406903/un-muerto-y-440-incidentes-enmarcaron-eleccion-en-oaxaca.

MG. 2007. Mexico's Constitution of 1917 with amendments through 2007. Available at: https://www.constituteproject.org/constitution/Mexico_2007.pdf.

Meyer, L. and Alvarado, B. M. (eds). 2010. New world of Indigenous resistance. San Francisco: City Lights.

Monjardin A.L. 1993. Juchitán: histories of discord. In Campbell H., L. Binford, M. Bartolomé and A. Barabas (eds.). Zapotec struggles: histories, politics and representations from Juchitan, Oaxaca. Washington D.C.: Smithsonian Institution Press. Pp. 65-80.

Nixon, R. 2011. Slow violence and the environmentalism of the poor. Cambridge: Harvard University Press.

Oceransky, S. 2011. Fighting the enclosure of wind. In K. Abramsky (ed.) Sparking a worldwide energy revolution. Oakland: AK Press. Pp. 505-522.

Owens, P. 2015. Economy of force. Cambridge: Cambridge University Press.

Paley, D. 2014. Drug war capitalism. Oakland: AK Press.

Paley, D. 2015. Ayotzinapa. Available at: http://www.revolutionbythebook.akpress.org/new-afterword-todawn-paleys-drug-war-capitalism/.

Rios, V. 2016. Mexico's special economic zones: white elephants? Washington D.C.: Woodrow Wilson International Center for Scholars. Available at: https://www.wilsoncenter.org/article/mexicos-specialeconomic-zones-white-elephants.

Rivas, S.C. 2015. Consulta definira futuro de inversiones Eolicas: Ocaso o resplandor. Available at: http://www.noticiasnet.mx/portal/sites/default/files/flipping_book/oax/2015/01/23/secc_a/files/assets/b asic-html/page20.html.

Roberts, L. and M. Elliott 2017. Good or bad vibrations? Impacts of anthropogenic vibration on the marine epibenthos. Science of the Total Environment 595: 255-268.

Rubin J.W. 1997. Decentering the regime: ethnicity, radicalism, and democracy in Juchitán, Mexico. Durham: Duke University Press.

SEDESOL. 2010. Catálogo de localidades. Available at: http://www.microrregiones.gob.mx/catloc/LocdeMun.aspx?tipo=clave\&campo=loc\&ent=20\&mun=04 3.

Sierra, M.T. 2005. The revival of Indigenous justice in Mexico. Political and Legal Anthropology Review 28: 52-72.

Sin-Embargo. 2015. Juez ordena suspender parque eólico en Juchitán, Oaxaca. Available at: http://www.sinembargo.mx/16-12-2015/1578990.

Smith, B.T. 2009. Pistoleros and popular movements: the politics of state formation in postrevolutionary Oaxaca, Lincoln: University of Nebraska Press.

Smith, J.M. 2012. Indigenous communities in Mexico fight corporate wind farms. Available at: http://upsidedownworld.org/main/mexico-archives-79/3952-indigenous-communities-in-mexico-fightcorporate-wind-farms.

Stephen, L. 2002. Zapata lives! Berkeley: University of California Press.

Stephen, L. 2005. Negotiating global, national, and local "Rights" in a Zapotec community. Political and Legal Anthropology Review 28: 133-150.

Stephen, L. 2013. We are the face of Oaxaca: testimony and social movements. Durham: Duke University Press.

Tabassum-Abbasi, M. Premalatha, T. Abbasi, and S.A. Abbasi. 2014. Wind energy: increasing deployment, rising environmental concerns. Renewable and Sustainable Energy Reviews 31: 270-288. 
Taylor, M. 2013. Climate change, relational vulnerability and human security. Climate and Development 5: 318-327.

Toledo, V.M. 2015. Ecocidio en México: la batalla final es por la vida. México: Grijalbo.

Tutino, J. 2007. The revolutionary capacity of rural communities: ecological autonomy and its demise. In Servín E., L. Reina and J. Tutino (eds.). Cycles of conflict, centuries of change. Durham: Duke University Press, 211-265.

USAID. 2009. Mexico wind farm case study. Available at: http://www.energytoolbox.org/gcre/wind_case_study.pdf.

Wood, D., S. Lozano, O. Romero-Hernandez and S. Romero-Hernandez. 2012. Wind energy potential in Mexico's northern border states. Woodrow Wilson International Center for Scholars. Available at: http://www.borderlegislators.org/pdfs/Publications/Wind_Energy_Potential_in_Mexico.pdf.

Zeitlin, J.F. 1989. Ranchers and Indians on the southern Isthmus of Tehuantepec. The Hispanic American Historical Review 69: 23-60.

Zografos C. and J. Martínez-Alier. 2009. The politics of landscape value: a case study of wind farm conflict in rural Catalonia. Environment and Planning A 41: 1726-1744. 